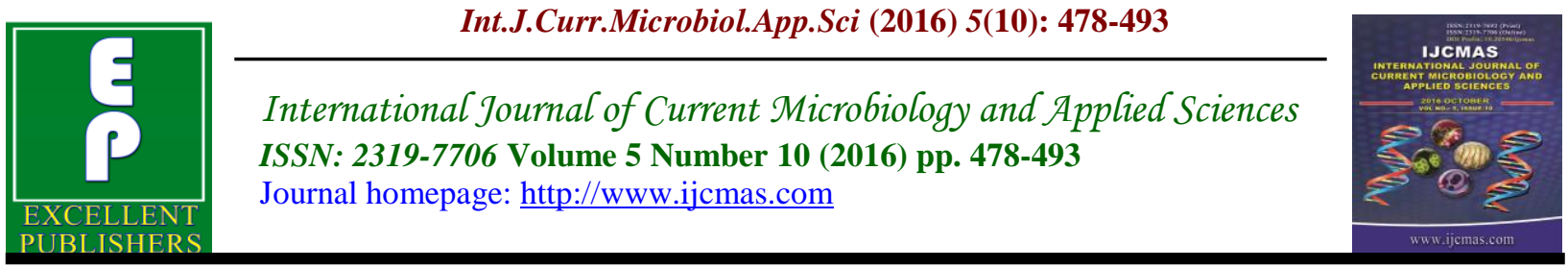

Original Research Article

http://dx.doi.org/10.20546/ijcmas.2016.510.054

\title{
Plasmid Profile of Multiple Antibiotics Resistant (MAR) Bacteria Isolated from Leachate Samples in Ebira Communities of Ekiti Central and Ekiti South, Ekiti State, Nigeria
}

\author{
A.T. Odeyemi*, O.S. Fasuan and O.Y. Olufowora \\ Microbiology Department, Ekiti State University, Ado-Ekiti, Nigeria \\ *Corresponding author
}

\section{Keywords}

Plasmid curing, leachate, MAR, Ebira Communities.

Article Info

Accepted:

17 September 2016 Available Online: 10 October 2016

\section{A B S T R A C T}

Plasmid curing of bacteria isolated from leachate samples in Ebira communities of Ekiti Central and South in Ekiti State senatorial district were analyzed. Microbial count, antibiotics sensitivity and plasmid profile were assayed using pour plate, disk diffusion and gel electrophoresis techniques respectively; while the plasmids were cured using acridine orange. The total bacterial, total coliform and total enteric bacteria counts of the leachate samples ranged from $0.64 \times 10^{8}$ to $0.85 \times$ $10^{9} \mathrm{CFU} / \mathrm{ml}, 0.78 \times 10^{8}$ to $0.76 \times 10^{9} \mathrm{CFU} / \mathrm{ml}$ and $1.90 \times 10^{8}$ to $2.30 \times 10^{9} \mathrm{CFU} / \mathrm{ml}$ respectively. The percentage distributions revealed that Escherichia coli with $29.2 \%$ had the highest frequency of occurrence while Enterobacter aerogenes had the lowest occurrence of $7.5 \%$. The antibiotics sensitivity test showed that the least percentage $(3 \%)$ of the isolates were resistant to ofloxacin while the highest percentage (99\%) of the isolates were resistant to cefuroxime. Multiple Antibiotics Resistant bacteria were subjected to plasmid analysis showing that nine (9) were devoid of plasmid while other six (6) isolates carry plasmid with high molecular weight, ranging from $9.41 \mathrm{kbp}$ to $23.130 \mathrm{kpb}$. Three of the MAR isolates (Escherichia coli, Pseudomonas aeruginosa and Enterococcus feacalis) were selected for curing. The three (3) retained resistance pattern to all antibiotics used aside Escherichia coli and Pseudomonas aeruginosa that became susceptible to ofloxacin after curing. Incidence of such MAR bacterial isolates in leachate samples is however an indication of possible environmental hazard.

\section{Introduction}

Antibiotics have been widely used for treating infections as well as promoting animal growth in aquaculture and farming over the past 60 years (Wang et al., 2015). Improper management on use and disposal, however, released large amounts of antibiotics into the environment causing the emergence and spread of antibiotic-resistant bacteria and antibiotic resistance genes in different environmental compartments (Wang et al., 2015; Pruden et al., 2006). According to World Health Organization (WHO), the resistance to antibiotics is an ability of bacterial population to survive the effect of inhibitory concentration of antimicrobial agents (Paramasivam et al., 
2007). Most microorganisms which are resistant to antibiotics emerge as a result of genetic change and subsequent selection processes by antibiotics. A bacterium that is normally susceptible to an agent might become resistant by mutation or acquisition of new genes. The resistance factor may be chromosomal, that developed as a result of spontaneous mutants and extrachromosomal resistance (plasmid resistance) (El-Sayed et al., 2015; Thankam et al., 2014).

Antibiotics resistance bacteria have been detected worldwide in various environments, including sediments (Luo et al., 2010); river (Garcia-Armisen et al., 2011; Luo et al., 2010); influent; effluent; and activated sludge of sewage treatment plants (Chen and Zhang 2013; Munir et al., 2011), pig farm (Zhu et al., 2013), and soil adjacent to pig farms (Wu et al., 2010) and so on.

However, antibiotics resistance has seldom been characterized in landfill or landfill leachate and despite the importance of microorganisms in the decomposition of organic matter in leachate; knowledge on the bacterial population is still fragmentary (Odeyemi et al., 2015).

Leachate being a complex mixture of organic, inorganic and many unidentified toxicants and toxic elements, may contain microbes which may be pathogenic producing toxins capable of causing public health hazards (Wang et al.,2015) and may pose risk of unknown magnitude to aquatic life. The large numbers of pathogenic and opportunistic bacteria may also be related to the presence of used disposable napkins and sanitary towels, clinical waste and domestic human origin waste like hypodermic needles and syringes (Odeyemi et al., 2011).

Hence this research was aimed at isolating different bacteria from landfill leachate, to know the antibiotic resistance pattern, to evaluate the presence and role of extrachromosomal genes (plasmid) in multiple antibiotics resistance bacteria in 'Ebira' communities within some selected eight local Governments in Ekiti state which include; Ado Local Government, Efon Local Govenment, Ekiti West local Govenment, Ijero Local Government, Irepodun/Ifelodun Local Government, Ekiti South West Local Government, Gboyin Local Govenment and Ise/Orun Local Government.

\section{Materials and Methods}

\section{Sampling area and collection of samples}

The basic area of focus in this research was the leachate sample obtained from the dumping sites located close to water bodies i.e. river, stream or well used in Ebira communities and clans of eight local governments in Ekiti State.

The local governments included those at the central and south senatorial districts in Ekiti State. The wastes disposed at these dumping sites are mainly domestic and household wastes such as; food residues from kitchen, hair and dead skin cells from bath/shower, water and human excreta (urine and faeces), and household ranging from lawn clippings to burned out light bulbs.

The leachate samples were collected aseptically with the aid of sterile needle and syringes from different sampling point. Each of the samples were collected in separate labeled sterile bottles and placed in an ice bag properly and transported to the Microbiology Laboratory of Microbiology Department, Faculty of Science, Ekiti State University. A total of twenty four samples were collected which were analyzed within $3 \mathrm{~h}$ in the Laboratory. 


\section{Microbiological Analysis}

\section{Preparation and enumeration of sample}

One millilitre each of leachate sample obtained was diluted in $9 \mathrm{ml}$ of warm $(\leq$ $\left.45^{\circ} \mathrm{C}\right)$ sterile diluents Buffered Peptone Water; incubated at room temperature for about 2-3hours to aid proliferation of microbes in the samples (APHA, 1985). Ten-fold dilution was prepared, using $1 \mathrm{ml}$ each of primary dilution following a vigorous shaking of the contents of the digester. Aliquots of $1 \mathrm{ml}$ of dilution $10^{-7}$ and $10^{-8}$ of each sample were introduced into well labeled Petri dishes using pour plating method for the enumeration of total bacterial, coliform and enteric counts; inverted and incubated aerobically at $37^{\circ} \mathrm{C}$ for $24 \mathrm{~h}$. Plates having between 30 and 300 colonies were selected for enumeration (Olutiola et al., 2000).

\section{Antibiotics Sensitivity}

\section{Standardization of Inoculum}

Standardization of inoculum was done by transferring about 4-5colonies of organisms into $9 \mathrm{ml}$ of normal saline, the turbidity was observed as more organisms were added and was compared with Mc Farlands standard $\left(0.1 \mathrm{~mL} \mathrm{BaCl}_{2}\right.$ and $9.9 \mathrm{~mL}$ Conc. $\left.\mathrm{HCl}\right)$ to reference the turbidity of bacterial suspensions and gives approximately $3.0 \mathrm{x}$ $10^{8} \mathrm{CFU} / \mathrm{ml}$ and so on (Palomino and Martin, 2009).

Using aseptic techniques, sterile swab sticks were placed into the broth culture and streaked on the Muller-Hinton agar plate. Antibiotics disc dispenser were then used to dispense the discs containing specific antibiotics. Flame-sterilized forceps were used to gently press the discs impregnated with varied antibiotics to the agar, then incubated at $37^{\circ} \mathrm{C}$ for 18 to $24 \mathrm{~h}$. After overnight incubation, the zone of inhibition was measured in $\mathrm{mm}$ and resistance/susceptibility pattern recorded in accordance with the CLSI (2012) standard. The Gram negative discs used contained cefotaxime (CAZ), cefuroxime (CRX), gentamycin (GEN), ofloxacin (OFL), augmentin (AUG), cefixime (CXM), nitrofuratoin (NIT) and ciprofloxacin (CPR). While Gram positive disc used possessed oxacillin (OXA), cloxacillin (COX), ceftazidine (CAZ), augmentin (AUG), cefotaxime (CTX), cefuroxime (CRX), ofloxacin (OFL) and gentamycin (GEN).

\section{Plasmid Extraction, Profiling and Curing}

TENS (Tris $25 \mathrm{mM}$ Ethyl-dimethyl tetraamine; EDTA $10 \mathrm{mM}$, sodium hydroxide; $\mathrm{NaOH} 0.1 \mathrm{~N}$ and sodium dodecyl sulphate) protocol describe by Liu et al. (1995) was employed in plasmid extraction. Approximately $1.5 \mathrm{ml}$ of overnight culture was spin for $1 \mathrm{~min}$ in a micro-centrifuge to pellet cells. Followed by gentle decant of the supernatant leaving $50 \mu \mathrm{L}$ together with cell pellet and vortex mixed at high speed to resuspend cells completely. A $300 \mu \mathrm{L}$ of TENS was then added. An inverting tube was used to Mix for 3 times until the mixture becomes sticky. Approximately 150 $\mu \mathrm{L}$ of $3.0 \mathrm{M}$ sodium acetate $(\mathrm{pH} 5.2)$ was then added to the preparation, followed by Vortex mixing. The preparation was spun for $5 \mathrm{~min}$ at $10,000 \mu \mathrm{g}$ in micro-centrifuge to pellet cell debris and chromosomal DNA and then the supernatant was transferred into a fresh tube; and mixed well with $900 \mu \mathrm{L}$ of ice-cold absolute ethanol. It was then spun again for $10 \mathrm{~min}$ to pellet plasmid DNA. (White pellet is observed) after which the supernatant was discarded; the pellet was rinsed twice with $1 \mathrm{ml}$ of $70 \%$ ethanol and dry pellet. Pellet was re-suspending in $30 \mu \mathrm{L}$ of buffer or distilled water for further use. 
The extracted plasmid DNA was electrophoresed on $0.8 \%$ agarose gel stained with ethidium bromide and visualized by UV-transillumination according to RobinsBrowne et al., (2004). (TENS composition: Tris $25 \mathrm{mM}$, Ethyl-dimethyl tetra-amine; EDTA $10 \mathrm{mM}$, Sodium hydroxide; $\mathrm{NaOH}$ $0.1 \mathrm{~N}$ and Sodium dodecyl sulphate; SDS $0.5 \%)$.

The plasmids were cured by introducing acridine orange according to the method of Brown (2000). Peptone water was prepared and supplemented with $0.1 \mathrm{mg} / \mathrm{ml}$ acridine orange. $20 \mu \mathrm{l}$ of overnight culture of the bacteria was subcultured into $5 \mathrm{mls}$ of the peptone water containing acridine orange. The samples were then incubated at $37^{\circ} \mathrm{C}$ for 24hours. After 24 hours of incubation, the isolates were seeded on Mueller Hinton agar plates. The antibiotic discs were planted on incubated plats and then incubated for $24 \mathrm{hrs}$ at $37^{\circ} \mathrm{C}$. After overnight incubation, the zones of inhibition were measured in $\mathrm{mm}$ and resistance/susceptibility pattern recorded (CLSI, 2012).

\section{Results and Discussion}

The average total bacteria count (TBC) of leachate samples A, B, C, D, E, F, G and H estimated ranged from $0.64 \times 10^{8}$ to $0.47 \times$ $10^{9} \mathrm{CFU} / \mathrm{ml}, 1.50 \times 10^{8} \mathrm{CFU} / \mathrm{ml}$ to $0.52 \times$ $10^{9} \mathrm{CFU} / \mathrm{ml}, 0.77 \times 10^{8} \mathrm{CFU} / \mathrm{ml}$ to $0.52 \times$ $10^{9} \mathrm{CFU} / \mathrm{ml}, 0.66 \times 10^{8} \mathrm{CFU} / \mathrm{ml}$ to $0.45 \times$ $10^{9} \mathrm{CFU} / \mathrm{ml}, 0.88 \times 10^{8} \mathrm{CFU} / \mathrm{ml}$ to $0.51 \times$ $10^{9} \mathrm{CFU} / \mathrm{ml}, 0.95 \times 10^{8} \mathrm{CFU} / \mathrm{ml}$ to $0.45 \times$ $10^{9} \mathrm{CFU} / \mathrm{ml}, 0.99 \times 10^{8} \mathrm{CFU} / \mathrm{ml}$ to $0.63 \times$ $10^{9} \mathrm{CFU} / \mathrm{ml}$ and $0.84 \times 10^{8} \mathrm{CFU} / \mathrm{ml}$ to $0.85 \times$ $10^{9} \mathrm{CFU} / \mathrm{ml}$, respectively; The range of estimated average total coliform count (TCC) of leachate samples were between $1.00 \times 10^{8} \mathrm{CFU} / \mathrm{ml}$ to $0.50 \times 10^{9} \mathrm{CFU} / \mathrm{ml}$, $1.39 \times 10^{8} \mathrm{CFU} / \mathrm{ml}$ to $0.68 \times 10^{9} \mathrm{CFU} / \mathrm{ml}$, $1.20 \times 10^{8} \mathrm{CFU} / \mathrm{ml}$ to $0.76 \times 10^{9} \mathrm{CFU} / \mathrm{ml}$,
$0.78 \times 10^{8} \mathrm{CFU} / \mathrm{ml}$ to $0.41 \times 10^{9} \mathrm{CFU} / \mathrm{ml}$, $0.91 \times 10^{8} \mathrm{CFU} / \mathrm{ml}$ to $0.55 \times 10^{9} \mathrm{CFU} / \mathrm{ml}$, $0.96 \times 10^{8} \mathrm{CFU} / \mathrm{ml}$ to $0.58 \times 10^{9} \mathrm{CFU} / \mathrm{ml}$, $1.12 \times 10^{8} \mathrm{CFU} / \mathrm{ml}$ to $0.59 \times 10^{9} \mathrm{CFU} / \mathrm{ml}$ and $0.85 \times 10^{8} \mathrm{CFU} / \mathrm{ml}$ to $0.44 \times$ $10^{9} \mathrm{CFU} / \mathrm{ml}$, respectively; while Enterococcal counts estimate ranged from $1.9 \times 10^{8} \mathrm{CFU} / \mathrm{ml}$ to $1.4 \times 10^{9} \mathrm{CFU} / \mathrm{ml}, 3.2$ $\times 10^{8} \mathrm{CFU} / \mathrm{ml}$ to $2.3 \times 10^{9} \mathrm{CFU} / \mathrm{ml}, 1.9 \times$ $10^{8} \mathrm{CFU} / \mathrm{ml}$ to $1.4 \times 10^{9} \mathrm{CFU} / \mathrm{ml}, 2.8 \times 10^{8}$ $\mathrm{CFU} / \mathrm{ml}$ to $2.3 \times 10^{9} \mathrm{CFU} / \mathrm{ml}, 2.6 \times 10^{8}$ $\mathrm{CFU} / \mathrm{ml}$ to $2.1 \times 10^{9} \mathrm{CFU} / \mathrm{ml}, 2.3 \times 10^{8}$ $\mathrm{CFU} / \mathrm{ml}$ to $1.9 \times 10^{9} \mathrm{CFU} / \mathrm{ml}, 3.1 \times 10^{8}$ $\mathrm{CFU} / \mathrm{ml}$ to $2.2 \times 10^{9} \mathrm{CFU} / \mathrm{ml}$ and $2.9 \times$ $10^{8} \mathrm{CFU} / \mathrm{ml}$ to $1.73 \times 10^{9} \mathrm{CFU} / \mathrm{ml}$, respectively (Table 1).

One hundred and six microbes belonging to six genera were Isolated. Escherichia coli $31(29.2 \%)$ had the highest frequency, followed by Enterococcus feacalis 28(26.4\%), Bacillus cereus 17(16\%), Staphylococcus aureus 12(11.3\%), Pseudomonas aeruginosa 10(9.4\%) and Enterobacter aerogenes which had the least distribution $8(7.5 \%)$ (Table 2).

The antibiotic resistance pattern of forty nine (49) Gram negative bacteria isolated from leachate samples are shown on Table 3 . The isolates demonstrated high level of resistance to augmentin, cefuroxine, cefixime and ceftazidine while ofloxacin and ciprofloxacin were the most effective of the entire antibiotics used. The range of pattern of antibiotic resistance of these bacteria were cefuroxime (96.8-100\%), cefixime (83.9-100\%), augmentin (62.5$100 \%)$, ceftazidine $(10-88 \%)$, nitrofurantoin (0-60\%), gentamycin (26-38\%), ciprofloxacin $(0-30 \%)$ and ofloxacin which have the least resistance $(3.2 \%)$.

The antibiotic resistance patterns of fifty seven (57) Gram-positive isolates are shown in Table 4. Their percentage resistance 
ranged from (70.6-100\%) to ceftazidine, (8.3-96.4\%) to cloxacillin, $(8.3-89.3 \%)$ to cefuroxine, (4-33\%) to gentamycin, (76.5$92.9 \%)$ to oxacillin and $(100 \%)$ resistance to augmentin. They exhibit least resistance to ofloxacin $(3-40 \%)$.

The occurrence of multiple antibiotic resistance (MAR) was higher among Gram positive isolates; while Gram-negative organisms had the highest number in a particular phenotype of Multiple resistance Pattern of the overall isolate CRX, GEN, CXM, AUG (16.9\%) (Table 5). The plasmid profile and molecular weight (kbp) of selected multiple antibiotics resistant (MAR) isolates are shown on Table 6. Seven $(46.7 \%)$ of the total organism analysed contain plasmid with molecular weight of $23.1 \mathrm{kbp}$ and $9.41 \mathrm{kbp} \mathrm{E}$. feacalis and $E$ coli carried one plasmid each with the same molecular weight of $23.1 \mathrm{kbp}, P$. aeruginosa had one plasmid with $9.41 \mathrm{kbp}$ while B.cereus .aerogenes and $S$. aureus had no plasmid.

Table 7 shows the resistance pattern of the plasmid cured Escherichia coli and Pseudomonas aeruginosa isolates. The percentage resistance of the Gram negative isolates to the antibiotics after curing are cefotaxime $(50 \%)$, cefuroxime $(100 \%)$, gentamycin $(50 \%)$, cefixime $(100 \%)$, ofloxacin (100\%), augmentin (100\%), nitrofurantoin $(50 \%)$, ciprofloxacin $(0 \%)$. Multiple antibiotics resistance pattern of Enterococcus feacalis after plasmid curing is also shown on Table 8. No plasmid was recovered from all $18(100 \%)$ cured isolates (Table 9).

Studies on the presence of multiple antibiotics resistance bacteria in landfill leachate are rarely reported. However, recent studies reveals that plasmid linked antibiotics resistance bacteria especially for pathogenic bacteria isolates are still of critical importance in water and leachate bacteria (Wang et al., 2015; Adeleye et al., 2011). Leachate is the liquid generated from moisture associated with materials within the landfill cell, after field capacity has been reached. Its production may be thought of as landfill percolation (Ikem et al., 2002).

The microbiological assessment of twenty four samples obtained from three (3) communities each in Eight (8) selected Local Government in Ekiti States revealed bacterial percentage of occurrence to be higher for Escherichia coli with 29.2\% followed by Enterococcus feacalis with $26.4 \%$ of occurrence, Bacillus cereus $11.3 \%$, Pseudomonas aeruginosa $9.4 \%$ and Enterobacter aerogenes has the least percentage of occurrence $7.5 \%$. This is in agreement with the report of Odeyemi et al. (2011), which stated Escherichia coli had the highest percentage occurrence in related study while Pseudomonas spp and Staphylococcus aureus has the least percentage of occurrence. Although E. coli which also showed more higher percentage is affirmed by the report of Lewis and Gattie (2002), which stated that Escherichia coli is able to withstand competition from other indigenous organisms with high growth rates. The presence of Escherichia coli is chiefly due to feacal contamination and it is an indication of the likely presence of other pathogenic bacteria which are capable of causing serious diseases. The bacterial isolated include species known to be involved in degradation of organic matters.

All bacteria isolated during this investigation have been reported by Ajayi et al., (2004) as potential pathogens. The presence of these potential pathogens in the leachate may be attributed to disposal of raw human feacal discharge and other human waste at the dump site of the leachate. Flores 
et al., (2007) reported that there is a regrowth of enteric bacteria in the cooler exterior of the dump so that populations of pathogenic organisms continue to survive and also that truly pathogenic form of microorganisms may survive in waste or leachate. From the result of antibiotic sensitivity test, a wide resistance to most of the antibiotics used was noted. The organisms were resistant due to production of enzymes which inactivate or modify antibiotic, changes in bacterial cell membrane, modification of target site, development of metabolic pathway by bacteria. These properties are acquired when bacteria undergo genetic changes. Such a genetic change may occur by mutation or by acquisition of new genetic materials (Cheesbrough, 2006; Odeyemi et al., 2015).

Selection of resistant organisms in nature may result in natural production of antibiotics by soil microorganisms, run -off from animal feed, crops or waste product from treated livestock or human (Ajayi et al., 2004). The passage of leachate through the top soil enables it to detoxify the effect of these antibiotics thus, having little or no effect on them. Erb et al., (2007) reported that the transfer of antibiotic resistance gene from one organism to another is a reason for high antibiotic resistance pattern in these organisms. When leachate is discharged into the water bodies, individual drinking this untreated water or using it for other domestic purpose may ingest the resistance strains and these strains will be part of human microflora. Therefore, infection caused by such organisms is very difficult to treat (Ajayi et al., 2004).

Fifteen (15) of the multiple antibiotics resistant isolate were randomly selected and subjected to plasmid analysis to detect the presence of extra- chromosomal DNA. Among the fifteen multiple resistant isolates tested, nine (9) were plasmid free while the other six (6) isolates carry plasmid with high molecular weight ranging from $9.41 \mathrm{kbp}$ $23.130 \mathrm{kpb}$. Enterococcus feacalis and Escherichia coli carried one plasmid each with the same molecular weight of $23.1 \mathrm{kbp}$, Pseudomonas aeruginosa had one plasmid with $9.41 \mathrm{kbp}$ while Bacillus cerus, Enterobacter aerogenes and Staphylococcus aureus had no plasmid. Plasmid analysis as one of the way to know whether gene coding for antibiotic resistance is located in plasmids in the same host cell this agrees with finding of Fujital et al., (1994).

In order to determine whether the observed resistance patterns in these isolates were plasmid mediated, three (3) selected multiple antibiotics resistant bacteria isolates including Escherichia coli, Pseudomonas aeruginosa and Enterococcus feacalis which had plasmid were further investigated by subjecting them to plasmid curing using acridine orange (Udeze et al., 2012).

After subjecting them to curing, they were then subjected to antibiotic susceptibility assay and it was discovered that about $90 \%$ of all drugs the isolates were resistant to before curing still retained their resistance profile after curing, aside the Gram negative isolates Escherichia coli and Pseudomonas aeruginosa that were both susceptible to ofloxacin.

For the confirmation of curing, the plasmid of cured bacteria was again isolated and after agarose gel electrophoresis the three cured isolate showed that they had lost their plasmids. This was in agreement with studies by Akter et al., 2011 which stated that the plasmid of cured bacteria were again isolated after agarose gel electrophoresis, the three cured isolates in that study showed that they had lost their plasmids. 
Table.1 Microbial Load of leachate Samples (CFU/ml)

\begin{tabular}{|c|c|c|c|c|c|c|}
\hline \multirow[b]{2}{*}{ Samples } & \multicolumn{2}{|c|}{ TBC } & \multicolumn{2}{|c|}{ TCC } & \multicolumn{2}{|c|}{ TEC } \\
\hline & $10^{8}$ & $10^{9}$ & $10^{8}$ & $10^{9}$ & $10^{8}$ & $10^{9}$ \\
\hline $\mathrm{A}_{1}$ & 1.00 & 0.75 & 1.00 & 0.60 & 2.00 & 1.50 \\
\hline $\mathrm{A}_{2}$ & 0.30 & 0.32 & 1.50 & 0.70 & 3.00 & 2.50 \\
\hline $\mathrm{A}_{3}$ & 0.61 & 0.35 & 0.50 & 0.20 & 0.70 & 0.20 \\
\hline Mean value & 0.64 & 0.47 & 1.00 & 0.50 & 1.90 & 1.40 \\
\hline $\mathrm{B}_{1}$ & 0.60 & 0.40 & 2.00 & 0.85 & 2.00 & 1.70 \\
\hline $\mathrm{B}_{2}$ & 3.20 & 0.80 & 1.05 & 0.65 & 3.50 & 2.50 \\
\hline $\mathrm{B}_{3}$ & 0.60 & 0.35 & 1.12 & 0.55 & 4.00 & 0.20 \\
\hline Mean value & 1.50 & 0.52 & 1.39 & 0.68 & 3.16 & 2.30 \\
\hline $\mathrm{C}_{1}$ & 0.82 & 0.50 & 1.13 & 0.68 & 0.90 & 1.70 \\
\hline $\mathrm{C}_{2}$ & 0.65 & 0.40 & 1.16 & 0.75 & 2.00 & 2.50 \\
\hline $\mathrm{C}_{3}$ & 0.83 & 0.65 & 1.30 & 0.85 & 3.00 & 2.70 \\
\hline Mean value & 0.77 & 0.52 & 1.20 & 0.76 & 1.96 & 1.40 \\
\hline $\mathrm{D}_{1}$ & 1.05 & 0.75 & 0.59 & 0.32 & 3.50 & 0.50 \\
\hline $\mathrm{D}_{2}$ & 0.63 & 0.45 & 0.85 & 0.60 & 0.90 & 1.50 \\
\hline D3 & 0.30 & 0.15 & 0.90 & 0.30 & 4.00 & 2.30 \\
\hline Mean value & 0.66 & 0.45 & 0.78 & 0.41 & 2.80 & 2.30 \\
\hline $\mathrm{E}_{1}$ & 1.05 & 0.62 & 0.85 & 0.30 & 3.50 & 3.00 \\
\hline $\mathrm{E}_{2}$ & 0.84 & 0.50 & 0.89 & 0.50 & 2.30 & 1.80 \\
\hline $\mathrm{E}_{3}$ & 0.74 & 0.40 & 1.00 & 0.85 & 1.90 & 1.50 \\
\hline Mean value & 0.88 & 0.51 & 0.91 & 0.55 & 2.60 & 2.10 \\
\hline $\mathrm{F}_{1}$ & 0.87 & 0.32 & 0.86 & 0.37 & 2.00 & 1.70 \\
\hline $\mathrm{F}_{2}$ & 0.85 & 0.30 & 0.90 & 0.70 & 1.50 & 1.20 \\
\hline $\mathrm{F}_{3}$ & 1.12 & 0.82 & 1.13 & 0.67 & 3.30 & 2.80 \\
\hline Mean value & 0.95 & 0.48 & 0.96 & 0.58 & 2.30 & 1.90 \\
\hline $\mathrm{G}_{1}$ & 0.63 & 0.45 & 1.05 & 0.55 & 1.90 & 1.40 \\
\hline $\mathrm{G}_{2}$ & 1.17 & 0.60 & 1.60 & 0.82 & 4.00 & 3.20 \\
\hline $\mathrm{G}_{3}$ & 1.11 & 0.85 & 0.70 & 0.40 & 3.40 & 1.90 \\
\hline Mean value & 0.99 & 0.63 & 1.1255 & 0.59 & 3.10 & 2.20 \\
\hline $\mathrm{H}_{1}$ & 0.58 & 0.40 & 0.85 & 0.40 & 3.20 & 2.30 \\
\hline $\mathrm{H}_{2}$ & 1.05 & 0.65 & 0.90 & 0.60 & 3.30 & 1.60 \\
\hline $\mathrm{H}_{3}$ & 0.89 & 0.67 & 0.85 & 0.32 & 2.30 & 1.30 \\
\hline Mean value & 0.84 & 0.57 & 0.85 & 0.44 & 2.90 & 1.73 \\
\hline \multicolumn{7}{|l|}{ Keys: } \\
\hline \multicolumn{3}{|c|}{$\begin{array}{l}\text { TBC-Total Bacteria Count, } \\
\text { TCC- Total Coliform Count }\end{array}$} & & TEC-Total & Enterococcal & Count \\
\hline \multicolumn{2}{|c|}{$\mathrm{A}_{1}$-Iworoko } & $\mathrm{E}_{1}$ Ita Ido & & $\mathrm{C}_{1}$-Ipoti & \multicolumn{2}{|l|}{$\mathrm{G}_{1}$-Ilumoba } \\
\hline \multicolumn{2}{|c|}{$\begin{array}{l}\mathrm{A}_{2} \text {-Afao } \\
\mathrm{A}_{3} \text {-Are }\end{array}$} & $\mathrm{E}_{2}$-Itawure & & $\mathrm{C}_{2}$.Iloro & \multicolumn{2}{|l|}{$\mathrm{G}_{2}$-Aisegba } \\
\hline \multirow{2}{*}{\multicolumn{2}{|c|}{$\begin{array}{l}\mathrm{A}_{3} \text {-Are } \\
\mathrm{B}_{1} \text { - Ilokun1 }\end{array}$}} & $\mathrm{E}_{3}$-alag & & $\mathrm{C}_{3}$ - Ijero & \multicolumn{2}{|l|}{$\mathrm{G}_{3}$-Ijan } \\
\hline & & $F_{1}$ Ogotu & & $\mathrm{D}_{1 \_ \text {Aramoko }}$ & \multicolumn{2}{|l|}{$\mathrm{H}_{1}$-Araromi } \\
\hline \multicolumn{2}{|c|}{$\mathrm{B}_{2}$-Ilokun 2} & $\mathrm{~F}_{2 \text {-Igbara odo }}$ & & $\mathrm{D}_{2}$ Erio & \multicolumn{2}{|l|}{$\begin{array}{l}\mathrm{H}_{2} \text {-Iworo } \\
\mathrm{H}_{2} \text {-Eriiivan }\end{array}$} \\
\hline \multicolumn{2}{|c|}{$\mathrm{B}_{3}$-Irasa } & $\mathrm{F}_{3}$-Edugbe & & $\mathrm{D}_{3}$ Erita & \multicolumn{2}{|l|}{$\mathrm{H}_{3}$-Erijiyan } \\
\hline
\end{tabular}


Table.2 Percentage Distribution of Bacteria Isolated from leachate Samples

\begin{tabular}{|c|c|c|c|c|c|c|c|c|c|c|}
\hline \multirow[t]{2}{*}{ Isolates } & \multicolumn{8}{|c|}{ Distribution(s) } & \multirow{2}{*}{$\begin{array}{l}\text { Nunmber } \\
\text { of isolates }\end{array}$} & \multirow{2}{*}{$\begin{array}{l}\text { Percentage } \\
\text { distribution }(\%)\end{array}$} \\
\hline & $\mathrm{A}$ & $\mathrm{B}$ & $\mathrm{C}$ & $\mathrm{D}$ & $\mathrm{E}$ & $\mathrm{F}$ & $\mathrm{G}$ & $\mathrm{H}$ & & \\
\hline Escherichia coli & 5 & 5 & 4 & 5 & 5 & 3 & 2 & 2 & 31 & $29.2 \%$ \\
\hline Enterococcus feacalis & 4 & 4 & 5 & 5 & 3 & 2 & 2 & 3 & 28 & $26.4 \%$ \\
\hline Bacillus cerus & 2 & 2 & 2 & 2 & 2 & 2 & 2 & 2 & 17 & $16.0 \%$ \\
\hline Staphylococcus aureus & 2 & 1 & 1 & 1 & 1 & 2 & 2 & 2 & 12 & $11.3 \%$ \\
\hline $\begin{array}{l}\text { Pseudomonasaerugino } \\
\text { sa }\end{array}$ & 2 & 1 & - & - & 1 & 2 & 2 & 2 & 10 & $9.4 \%$ \\
\hline $\begin{array}{c}\text { Enterobacteraerogenes } \\
\text { Total }\end{array}$ & 1 & - & 2 & 2 & 1 & 1 & 1 & 1 & $\begin{array}{c}08 \\
106\end{array}$ & $\begin{array}{l}7.5 \% \\
100 \%\end{array}$ \\
\hline
\end{tabular}

Keys:

$\begin{array}{ll}\text { A-Irepodun/Ifelodunlocal government } & \text { B- Ado local government } \\ \text { C-Ijero local government } & \text { D- Ekiti west local government } \\ \text { E-Efon local government } & \text { F- Ekiti south west local government } \\ \text { G-Gboyin local government } & \text { H - Ise-orun local government }\end{array}$

Table.3 Antibiotics Resistance Pattern of Gram Negative Bacteria Isolated from Water Samples

\begin{tabular}{|c|c|c|c|c|c|c|c|c|c|}
\hline \multirow{2}{*}{$\begin{array}{c}\text { Test } \\
\text { Organism }\end{array}$} & \multicolumn{8}{|c|}{ Antibiotics } & \multirow[b]{2}{*}{ Phenotype of resistance pattern } \\
\hline & CAZ & CRX & GEN & CXM & OFL & AUG & NIT & CPR & \\
\hline \multicolumn{10}{|l|}{ Escherichia coli } \\
\hline 1 & $\mathrm{R}$ & $\mathrm{R}$ & S & $\mathrm{R}$ & S & $\mathrm{R}$ & S & S & CAZ,CRX,CXM,AUG \\
\hline 2 & $\mathrm{R}$ & $\mathrm{R}$ & $\mathrm{R}$ & $\mathrm{R}$ & S & $\mathrm{R}$ & S & S & CAZ,CRX,CXM,AUG \\
\hline 3 & $\mathrm{R}$ & $\mathrm{R}$ & I & $\mathrm{R}$ & S & $\mathrm{R}$ & $\mathrm{R}$ & S & CAZ, CRX, CXM, AUG, NIT \\
\hline 4 & $\mathrm{~S}$ & $\mathrm{R}$ & $\mathrm{S}$ & $\mathrm{R}$ & $\mathrm{S}$ & $\mathrm{R}$ & $\mathrm{S}$ & I & CRX,CXM,AUG \\
\hline 5 & I & S & S & S & S & $\mathrm{R}$ & S & S & AUG \\
\hline 6 & $\mathrm{R}$ & $\mathrm{R}$ & I & $\mathrm{R}$ & $\mathrm{R}$ & $\mathrm{R}$ & S & $\mathrm{R}$ & CAZ,CRX,CXM,OFL,AUG,CPR \\
\hline 7 & $\mathrm{R}$ & $\mathrm{R}$ & S & $\mathrm{R}$ & S & $\mathrm{R}$ & S & S & CAZ,CRX,CXM,AUG \\
\hline 8 & $\mathrm{R}$ & $\mathrm{R}$ & $\mathrm{S}$ & $\mathrm{R}$ & $\mathrm{S}$ & $\mathrm{R}$ & $\mathrm{S}$ & $\mathrm{S}$ & CAZ,CRX,CXM,AUG \\
\hline 9 & $\mathrm{R}$ & $\mathrm{R}$ & S & $\mathrm{R}$ & S & $\mathrm{R}$ & S & S & CAZ,CRX,CXM.AUG \\
\hline 10 & $\mathrm{R}$ & $\mathrm{R}$ & $\mathrm{S}$ & $\mathrm{R}$ & $\mathrm{S}$ & $\mathrm{R}$ & $\mathrm{S}$ & I & CAZ,CRX,CXM,AUG \\
\hline 11 & $\mathrm{R}$ & $\mathrm{R}$ & $S$ & $\mathrm{R}$ & S & $\mathrm{R}$ & S & $S$ & CAZ,CRX,CXM,AUG \\
\hline 12 & $\mathrm{R}$ & $\mathrm{R}$ & $S$ & $\mathrm{R}$ & S & $\mathrm{R}$ & S & I & CAZ,CRX,CXM,AUG, \\
\hline 13 & I & $\mathrm{R}$ & I & $\mathrm{R}$ & S & $\mathrm{R}$ & $\mathrm{R}$ & S & CRX,CXM,AUG,NIT \\
\hline 14 & $\mathrm{R}$ & $\mathrm{R}$ & $\mathrm{S}$ & $\mathrm{R}$ & $\mathrm{S}$ & $\mathrm{R}$ & $\mathrm{S}$ & I & CAZ,CRX,CXM,AUG \\
\hline 15 & I & $\mathrm{R}$ & $\mathrm{R}$ & $\mathrm{R}$ & S & $\mathrm{R}$ & S & S & CRX,GEN,CXM,AUG \\
\hline 16 & $\mathrm{R}$ & $\mathrm{R}$ & $S$ & $\mathrm{R}$ & S & $\mathrm{R}$ & S & S & CAZ,CRX,CXM,OFL \\
\hline 17 & $\mathrm{R}$ & $\mathrm{R}$ & $S$ & $\mathrm{R}$ & S & $\mathrm{R}$ & S & S & CAZ,CRX,CXM,AUG \\
\hline 18 & I & $\mathrm{R}$ & $\mathrm{R}$ & $\mathrm{R}$ & $\mathrm{S}$ & $\mathrm{R}$ & $\mathrm{S}$ & $\mathrm{S}$ & CRX,GEN,CXM,AUG \\
\hline 19 & $\mathrm{R}$ & $\mathrm{R}$ & S & $\mathrm{R}$ & S & $\mathrm{R}$ & S & I & CAZ,CRX,GEN,OFL \\
\hline 20 & I & $\mathrm{R}$ & $\mathrm{R}$ & $\mathrm{R}$ & S & $\mathrm{R}$ & I & S & CRX,GEN,CXM AUG \\
\hline 21 & $\mathrm{R}$ & $\mathrm{R}$ & S & $\mathrm{R}$ & S & $\mathrm{R}$ & S & S & CAZ,CRX,AUG,CXM \\
\hline 22 & $\mathrm{R}$ & $\mathrm{R}$ & S & $\mathrm{R}$ & S & $\mathrm{R}$ & I & S & CAZ,CRX,AUG,CXM \\
\hline 23 & $\mathrm{R}$ & $\mathrm{R}$ & I & $\mathrm{R}$ & S & $\mathrm{R}$ & S & S & CAZ,CRX,AUG,CXM \\
\hline 24 & $\mathrm{R}$ & $\mathrm{R}$ & $\mathrm{R}$ & S & I & $\mathrm{R}$ & $\mathrm{I}$ & S & CAZ,CRX,GEN,AUG \\
\hline 25 & $\mathrm{R}$ & $\mathrm{R}$ & S & $\mathrm{R}$ & S & $\mathrm{R}$ & S & S & CAZ,CRX,CXM,AUG \\
\hline 26 & $\mathrm{R}$ & $\mathrm{R}$ & $S$ & $\mathrm{R}$ & S & $\mathrm{R}$ & S & I & CAZ,CRX,CXM,AUG \\
\hline 27 & $\mathrm{R}$ & $\mathrm{R}$ & S & $\mathrm{R}$ & S & $\mathrm{R}$ & S & $\mathrm{S}$ & CAZ,CRX,CXM,AUG \\
\hline
\end{tabular}




\begin{tabular}{|c|c|c|c|c|c|c|c|c|c|}
\hline 28 & $\mathrm{R}$ & $\mathrm{R}$ & S & $\mathrm{R}$ & $\mathrm{S}$ & $\mathrm{R}$ & $\mathrm{S}$ & $\mathrm{S}$ & CAZ,CRX,CXM,AUG \\
\hline 29 & $\mathrm{R}$ & $\mathrm{R}$ & $\mathrm{R}$ & S & $\mathrm{I}$ & $\mathrm{R}$ & $\mathrm{I}$ & $\mathrm{S}$ & CAZ,CRX,GEN,AUG \\
\hline 30 & $\mathrm{R}$ & $\mathrm{R}$ & $\mathrm{R}$ & S & $\mathrm{I}$ & $\mathrm{R}$ & $\mathrm{I}$ & $\mathrm{S}$ & CAZ,CRX,GEN,AUG \\
\hline 31 & $\mathrm{R}$ & $\mathrm{R}$ & $\mathrm{R}$ & S & $\mathrm{I}$ & $\mathrm{R}$ & $\mathrm{I}$ & $\mathrm{S}$ & CAZ,CRX,GEN,AUG \\
\hline $\begin{array}{c}\% \text { Resistance } \\
\text { to } \\
\text { Antiobiotics }\end{array}$ & 81 & 97 & 26 & 84 & 3 & 100 & 7 & 3 & \\
\hline \multicolumn{10}{|c|}{ Enterobacter aerogenese } \\
\hline 1 & $\mathrm{R}$ & $\mathrm{R}$ & $\mathrm{R}$ & $\mathrm{R}$ & $\mathrm{S}$ & I & $\mathrm{S}$ & I & CAZ,CRX,GEN,CXM \\
\hline 2 & $\mathrm{R}$ & $\mathrm{R}$ & $\mathrm{S}$ & $\mathrm{R}$ & $\mathrm{S}$ & $\mathrm{R}$ & $\mathrm{S}$ & I & CAZ,CRX,CXM,AUG \\
\hline 3 & I & $\mathrm{R}$ & I & I & $S$ & $\mathrm{R}$ & I & $\mathrm{S}$ & CRX,AUG \\
\hline 4 & $\mathrm{R}$ & $\mathrm{R}$ & $\mathrm{R}$ & $\mathrm{R}$ & $\mathrm{S}$ & I & $\mathrm{S}$ & I & CAZ,CRX,GEN,CXM \\
\hline 5 & $\mathrm{R}$ & $\mathrm{R}$ & $\mathrm{R}$ & $\mathrm{R}$ & $\mathrm{S}$ & I & $\mathrm{S}$ & I & CAZ,CRX,GEN,CXM \\
\hline 6 & $\mathrm{R}$ & $\mathrm{R}$ & S & $\mathrm{R}$ & $S$ & $\mathrm{R}$ & $\mathrm{S}$ & I & CAZ,CRX,CXM,AUG \\
\hline 7 & $\mathrm{R}$ & $\mathrm{R}$ & S & $\mathrm{R}$ & $S$ & $\mathrm{R}$ & $\mathrm{S}$ & I & CAZ,CRX,CXM,AUG \\
\hline 8 & $\mathrm{R}$ & $\mathrm{R}$ & S & $\mathrm{R}$ & $\mathrm{S}$ & $\mathrm{R}$ & $\mathrm{S}$ & I & CAZ,CRX,CXM,AUG \\
\hline $\begin{array}{l}\% \text { Resistance } \\
\text { to antibiotics }\end{array}$ & 88 & 100 & 38 & 88 & 0 & 63 & 0 & 0 & \\
\hline \multicolumn{10}{|c|}{ Pseudomonas aeruginosa } \\
\hline 1 & $\mathrm{~S}$ & $\mathrm{R}$ & $\mathrm{R}$ & $\mathrm{R}$ & $\mathrm{R}$ & $\mathrm{R}$ & $\mathrm{S}$ & $\mathrm{I}$ & CRX,GEN,CXM,OFL,AUG \\
\hline 2 & I & $\mathrm{R}$ & I & $\mathrm{R}$ & $\mathrm{S}$ & $\mathrm{R}$ & $\mathrm{R}$ & S & CRX,CXM,AUG,NIT \\
\hline 3 & $\mathrm{~S}$ & $\mathrm{R}$ & I & $\mathrm{R}$ & $\mathrm{S}$ & $\mathrm{R}$ & $\mathrm{R}$ & $\mathrm{I}$ & CRX,CXM,AUG,NIT \\
\hline 4 & $\mathrm{~S}$ & $\mathrm{R}$ & $\mathrm{R}$ & $\mathrm{R}$ & $\mathrm{R}$ & $\mathrm{R}$ & $\mathrm{S}$ & $\mathrm{S}$ & CRX,GEN,CXM,OFL,AUG \\
\hline 5 & $\mathrm{R}$ & $\mathrm{R}$ & I & $\mathrm{R}$ & S & $\mathrm{R}$ & $\mathrm{I}$ & $\mathrm{S}$ & CAZ,CRX,CXM,AUG \\
\hline 6 & I & $\mathrm{R}$ & I & $\mathrm{R}$ & S & $\mathrm{R}$ & $\mathrm{R}$ & $\mathrm{R}$ & CRX,CXM,AUG,NIT,CPR \\
\hline 7 & I & $\mathrm{R}$ & I & $\mathrm{R}$ & $\mathrm{S}$ & $\mathrm{R}$ & $\mathrm{R}$ & $\mathrm{R}$ & CRX,CXM,AUG,NIT,CPR \\
\hline 8 & I & $\mathrm{R}$ & I & $\mathrm{R}$ & S & $\mathrm{R}$ & $\mathrm{R}$ & $\mathrm{R}$ & CRX,CXM,AUG,NIT,CPR \\
\hline 9 & $\mathrm{~S}$ & $\mathrm{R}$ & $\mathrm{R}$ & $\mathrm{R}$ & $\mathrm{R}$ & $\mathrm{R}$ & $\mathrm{S}$ & I & CRX,GEN,CXM,OFL,AUG \\
\hline 10 & I & $\mathrm{R}$ & I & $\mathrm{R}$ & S & $\mathrm{R}$ & $\mathrm{R}$ & $\mathrm{S}$ & CRX,CXM,AUG,NIT \\
\hline $\begin{array}{l}\% \text { Resistance } \\
\text { to antibiotics }\end{array}$ & 10 & 100 & 30 & 100 & 30 & 100 & 60 & 30 & \\
\hline
\end{tabular}

Keys: CAZ - Cefotaxime, CRX - Cefuroxime, GEN - Gentamycin, CXM - Cefixime, OFL -Ofloxacin, AUG - Augmentin, NIT - Nitrofurantoin, CPR - Ciprofloxacin, $\mathrm{R}$ - Resistant, S - Sensitive, I - Intermediate

Table.4 Antibiotics Resistance Pattern of Gram Positive Bactria Isolated from Leachate Samples

\begin{tabular}{|c|c|c|c|c|c|c|c|c|c|}
\hline \multirow[b]{2}{*}{ Test Organism } & \multicolumn{8}{|c|}{ Antibiotics } & \multirow[b]{2}{*}{ Phenotype of resistance pattern } \\
\hline & CAZ & CTX & GEN & COX & OFL & CRX & OXA & AUG & \\
\hline \multicolumn{10}{|c|}{ Enterococcus faecalis } \\
\hline 1 & $\mathrm{R}$ & S & S & $\mathrm{R}$ & S & S & $\mathrm{R}$ & $\mathrm{R}$ & CAZ,COX,OXA,AUG \\
\hline 2 & $\mathrm{R}$ & $S$ & $\mathrm{~S}$ & $\mathrm{R}$ & $S$ & S & $\mathrm{R}$ & $\mathrm{R}$ & CAZ,COX,OXA,AUG \\
\hline 3 & $\mathrm{R}$ & S & S & $\mathrm{R}$ & S & S & $\mathrm{R}$ & $\mathrm{R}$ & CAZ,COX,OXA,AUG \\
\hline 4 & $S$ & S & I & $\mathrm{R}$ & $\mathrm{S}$ & $\mathrm{R}$ & $\mathrm{R}$ & $\mathrm{R}$ & COX ,CRX,OXA,AUG \\
\hline 5 & $S$ & S & I & $\mathrm{R}$ & $S$ & $\mathrm{R}$ & $\mathrm{R}$ & $\mathrm{R}$ & COX,CRX,OXA,AUG \\
\hline 6 & $\mathrm{R}$ & $S$ & $S$ & $\mathrm{R}$ & $S$ & $\mathrm{R}$ & $\mathrm{R}$ & $\mathrm{R}$ & CAZ,COX,CRX,OXA,AUG \\
\hline 7 & $\mathrm{R}$ & $S$ & $S$ & $S$ & $S$ & $\mathrm{R}$ & $\mathrm{R}$ & $\mathrm{R}$ & CAZ,CRX,OXA,AUG \\
\hline 8 & I & S & S & $\mathrm{R}$ & S & $\mathrm{R}$ & $\mathrm{R}$ & $\mathrm{R}$ & COX,CRX,OXA,AUG \\
\hline 9 & $\mathrm{R}$ & S & S & $\mathrm{R}$ & $\mathrm{S}$ & $\mathrm{R}$ & $\mathrm{R}$ & $\mathrm{R}$ & CAZ,COX,CRX,OXA,AUG \\
\hline 10 & $\mathrm{R}$ & S & S & $\mathrm{R}$ & S & $\mathrm{R}$ & $\mathrm{R}$ & $\mathrm{R}$ & CAZ,COX,CRX,OXA,AUG \\
\hline 11 & $\mathrm{R}$ & $S$ & I & $\mathrm{R}$ & $S$ & $\mathrm{R}$ & $\mathrm{R}$ & $\mathrm{R}$ & CAZ,COX,CRX,OXA,AUG \\
\hline 12 & $\mathrm{R}$ & $S$ & I & $\mathrm{R}$ & $S$ & $\mathrm{R}$ & I & $\mathrm{R}$ & CAZ,COX,CRX,AUG \\
\hline 13 & $\mathrm{R}$ & S & I & $\mathrm{R}$ & S & $\mathrm{R}$ & I & $\mathrm{R}$ & CAZ,COX,CRX,AUG \\
\hline 14 & $\mathrm{R}$ & $S$ & $S$ & $\mathrm{R}$ & $S$ & $\mathrm{R}$ & $\mathrm{R}$ & $\mathrm{R}$ & CAZ,COX,CRX,OXA,AUG \\
\hline
\end{tabular}




\begin{tabular}{|c|c|c|c|c|c|c|c|c|c|}
\hline 15 & I & $\mathrm{S}$ & I & $\mathrm{R}$ & $\mathrm{S}$ & $\mathrm{R}$ & $\mathrm{R}$ & $\mathrm{R}$ & COX,CRX,OXA,AUG \\
\hline 16 & $\mathrm{R}$ & $\mathrm{S}$ & $\mathrm{S}$ & $\mathrm{R}$ & $\mathrm{S}$ & $\mathrm{R}$ & $\mathrm{R}$ & $\mathrm{R}$ & CAZ,COX,CRX,OXA,AUG \\
\hline 17 & $\mathrm{R}$ & $\mathrm{S}$ & $\mathrm{S}$ & $\mathrm{R}$ & $\mathrm{S}$ & $\mathrm{R}$ & $\mathrm{R}$ & $\mathrm{R}$ & CAZ, COX, CRX, OXA, AUG \\
\hline 18 & $\mathrm{R}$ & $\mathrm{S}$ & $\mathrm{S}$ & $\mathrm{R}$ & $\mathrm{S}$ & $\mathrm{R}$ & $\mathrm{R}$ & $\mathrm{R}$ & CAZ, COX, CRX, OXA, AUG \\
\hline 19 & $\mathrm{R}$ & $\mathrm{S}$ & $\mathrm{R}$ & $\mathrm{R}$ & $\mathrm{S}$ & $\mathrm{R}$ & $\mathrm{R}$ & $\mathrm{R}$ & CAZ,GEN,COX,CRX,OXA,AUG \\
\hline 20 & $\mathrm{R}$ & $\mathrm{S}$ & $\mathrm{S}$ & $\mathrm{R}$ & $\mathrm{S}$ & $\mathrm{R}$ & $\mathrm{R}$ & $\mathrm{R}$ & CAZ, COX, CRX, OXA, AUG \\
\hline 21 & $\mathrm{R}$ & $\mathrm{S}$ & I & $\mathrm{R}$ & $\mathrm{S}$ & $\mathrm{R}$ & $\mathrm{R}$ & $\mathrm{R}$ & CAZ, COX,CRX,OXA,AUG \\
\hline 22 & $\mathrm{R}$ & $\mathrm{S}$ & $\mathrm{S}$ & $\mathrm{R}$ & $\mathrm{S}$ & $\mathrm{R}$ & $\mathrm{R}$ & $\mathrm{R}$ & CAZ,COX,CRX,OXA,AUG \\
\hline 23 & $\mathrm{R}$ & $\mathrm{S}$ & I & $\mathrm{R}$ & $\mathrm{S}$ & $\mathrm{R}$ & $\mathrm{R}$ & $\mathrm{R}$ & CAZ,COX,CRX,OXA,AUG \\
\hline 24 & $\mathrm{R}$ & $\mathrm{S}$ & I & $\mathrm{R}$ & $\mathrm{S}$ & $\mathrm{R}$ & $\mathrm{R}$ & $\mathrm{R}$ & CAZ,COX,CRX,OXA,AUG \\
\hline 25 & $\mathrm{~S}$ & $\mathrm{~S}$ & $\mathrm{~S}$ & $\mathrm{R}$ & $\mathrm{S}$ & $\mathrm{R}$ & $\mathrm{R}$ & $\mathrm{R}$ & COX,CRX,OXA,AUG \\
\hline 26 & $\mathrm{~S}$ & $\mathrm{~S}$ & $\mathrm{~S}$ & $\mathrm{R}$ & $\mathrm{S}$ & $\mathrm{R}$ & $\mathrm{R}$ & $\mathrm{R}$ & COX,CRX,OXA,AUG \\
\hline 27 & $\mathrm{~S}$ & $\mathrm{~S}$ & $\mathrm{~S}$ & $\mathrm{R}$ & $\mathrm{S}$ & $\mathrm{R}$ & $\mathrm{R}$ & $\mathrm{R}$ & COX,CRX,OXA,AUG \\
\hline 28 & $\mathrm{~S}$ & $\mathrm{~S}$ & $\mathrm{~S}$ & $\mathrm{R}$ & $\mathrm{S}$ & $\mathrm{R}$ & $\mathrm{R}$ & $\mathrm{R}$ & COX,CRX,OXA,AUG \\
\hline $\begin{array}{l}\% \text { Resistance to } \\
\text { antibiotics }\end{array}$ & 71 & 0 & 4 & 96 & 0 & 89 & 93 & 100 & \\
\hline \multicolumn{10}{|c|}{ Staphylococcus aureus } \\
\hline 1 & $\mathrm{R}$ & $\mathrm{S}$ & $\mathrm{S}$ & $\mathrm{R}$ & $\mathrm{S}$ & $\mathrm{R}$ & I & $\mathrm{R}$ & CAZ,COX,CRX,AUG \\
\hline 2 & $\mathrm{R}$ & $\mathrm{S}$ & $\mathrm{S}$ & $\mathrm{R}$ & $\mathrm{S}$ & $\mathrm{S}$ & $\mathrm{R}$ & $\mathrm{R}$ & CAZ,COX,OXA,AUG \\
\hline 3 & $\mathrm{R}$ & $\mathrm{S}$ & $\mathrm{S}$ & $\mathrm{R}$ & $\mathrm{R}$ & $\mathrm{S}$ & $\mathrm{R}$ & $\mathrm{R}$ & COX,OFL,OXA,AUG \\
\hline 4 & $\mathrm{R}$ & $\mathrm{S}$ & $\mathrm{R}$ & $\mathrm{R}$ & $\mathrm{S}$ & $\mathrm{I}$ & $\mathrm{R}$ & $\mathrm{R}$ & CAZ, GEN, COX, OXA, AUG \\
\hline 5 & $\mathrm{R}$ & $\mathrm{S}$ & I & $\mathrm{R}$ & $\mathrm{S}$ & $\mathrm{S}$ & $\mathrm{R}$ & $\mathrm{R}$ & CAZ,COX,OXA,AUG \\
\hline 6 & $\mathrm{R}$ & $\mathrm{S}$ & $\mathrm{R}$ & $\mathrm{R}$ & $\mathrm{S}$ & $\mathrm{I}$ & $\mathrm{R}$ & $\mathrm{R}$ & CAZ, GEN, COX, OXA, AUG \\
\hline 7 & $\mathrm{R}$ & $\mathrm{S}$ & $\mathrm{S}$ & $\mathrm{R}$ & $\mathrm{S}$ & $\mathrm{S}$ & $\mathrm{R}$ & $\mathrm{R}$ & CAZ,COX,OXA,AUG \\
\hline 8 & $\mathrm{R}$ & $\mathrm{S}$ & I & $\mathrm{R}$ & $\mathrm{S}$ & $\mathrm{S}$ & $\mathrm{R}$ & $\mathrm{R}$ & CAZ,COX,OXA,AUG \\
\hline 9 & $\mathrm{R}$ & $\mathrm{S}$ & I & $\mathrm{R}$ & $\mathrm{S}$ & $\mathrm{S}$ & $\mathrm{R}$ & $\mathrm{R}$ & CAZ,COX,OXA,AUG \\
\hline 10 & $\mathrm{R}$ & $\mathrm{S}$ & I & $\mathrm{R}$ & $\mathrm{S}$ & $\mathrm{S}$ & $\mathrm{R}$ & $\mathrm{R}$ & CAZ,COX,OXA,AUG \\
\hline 11 & $\mathrm{R}$ & $\mathrm{S}$ & $\mathrm{R}$ & $\mathrm{R}$ & $\mathrm{S}$ & $\mathrm{I}$ & $\mathrm{R}$ & $\mathrm{R}$ & CAZ, GEN, COX, OXA, AUG \\
\hline 12 & $\mathrm{R}$ & $\mathrm{S}$ & $\mathrm{R}$ & $\mathrm{R}$ & $\mathrm{S}$ & $\mathrm{I}$ & $\mathrm{R}$ & $\mathrm{R}$ & CAZ, GEN, COX, OXA, AUG \\
\hline $\begin{array}{l}\% \text { Resistance to } \\
\text { antibiotics }\end{array}$ & 100 & 0 & 33 & 100 & 8 & 8 & 92 & 100 & \\
\hline \multicolumn{10}{|l|}{ Bacillus cerus } \\
\hline 1 & I & $\mathrm{S}$ & $\mathrm{S}$ & $\mathrm{R}$ & $\mathrm{S}$ & $\mathrm{S}$ & $\mathrm{R}$ & $\mathrm{R}$ & COX,OXA,AUG \\
\hline 2 & I & $\mathrm{S}$ & I & $\mathrm{R}$ & $\mathrm{S}$ & $\mathrm{S}$ & $\mathrm{R}$ & $\mathrm{R}$ & COX,OXA,AUG \\
\hline 3 & $\mathrm{R}$ & $\mathrm{S}$ & $\mathrm{S}$ & $\mathrm{R}$ & $\mathrm{S}$ & $\mathrm{S}$ & $\mathrm{R}$ & $\mathrm{R}$ & CAZ,COX,OXA,AUG \\
\hline 4 & $\mathrm{R}$ & $\mathrm{S}$ & $\mathrm{S}$ & $\mathrm{R}$ & $\mathrm{S}$ & $\mathrm{S}$ & $\mathrm{R}$ & $\mathrm{R}$ & CAZ,COX,OXA,AUG \\
\hline 5 & $\mathrm{R}$ & $\mathrm{S}$ & $\mathrm{S}$ & $\mathrm{R}$ & $\mathrm{S}$ & $\mathrm{S}$ & $\mathrm{R}$ & $\mathrm{R}$ & CAZ,COX,OXA,AUG \\
\hline 6 & $\mathrm{R}$ & $\mathrm{S}$ & $\mathrm{S}$ & $\mathrm{R}$ & $\mathrm{S}$ & $\mathrm{S}$ & $\mathrm{R}$ & $\mathrm{R}$ & CAZ,COX,OXA,AUG \\
\hline 7 & $\mathrm{R}$ & $\mathrm{S}$ & $\mathrm{S}$ & $\mathrm{R}$ & $\mathrm{S}$ & $\mathrm{R}$ & $\mathrm{I}$ & $\mathrm{R}$ & CAZ,COX,CRX,AUG \\
\hline 8 & $\mathrm{R}$ & $\mathrm{S}$ & I & $\mathrm{R}$ & $\mathrm{S}$ & $\mathrm{R}$ & $\mathrm{S}$ & $\mathrm{R}$ & CAZ,COX,CRX,AUG \\
\hline 9 & $\mathrm{R}$ & $\mathrm{S}$ & I & $\mathrm{R}$ & $\mathrm{S}$ & $\mathrm{R}$ & $\mathrm{R}$ & $\mathrm{R}$ & CAZ,COX,CRX,OXA,AUG \\
\hline 10 & $\mathrm{R}$ & $\mathrm{S}$ & $\mathrm{S}$ & $\mathrm{R}$ & $\mathrm{S}$ & $\mathrm{R}$ & I & $\mathrm{R}$ & CAZ,COX,CRX,,AUG \\
\hline 11 & $\mathrm{R}$ & $\mathrm{S}$ & $\mathrm{S}$ & $\mathrm{R}$ & $\mathrm{S}$ & $\mathrm{R}$ & $\mathrm{R}$ & $\mathrm{R}$ & CAZ,COX,CRX,OXA,AUG \\
\hline 12 & I & $\mathrm{S}$ & $\mathrm{R}$ & I & I & $\mathrm{R}$ & $\mathrm{R}$ & $\mathrm{R}$ & GEN,CRX,OXA,AUG \\
\hline 13 & $\mathrm{R}$ & $\mathrm{S}$ & $\mathrm{S}$ & $\mathrm{R}$ & $\mathrm{S}$ & $\mathrm{R}$ & $\mathrm{R}$ & $\mathrm{R}$ & CAZ,COX,CRX,OXA,AUG \\
\hline 14 & $\mathrm{R}$ & $\mathrm{S}$ & $\mathrm{S}$ & $\mathrm{R}$ & $\mathrm{S}$ & $\mathrm{R}$ & $\mathrm{R}$ & $\mathrm{R}$ & CAZ,COX,CRX,OXA,AUG \\
\hline 15 & I & $\mathrm{S}$ & $\mathrm{S}$ & $\mathrm{R}$ & $\mathrm{S}$ & $\mathrm{S}$ & $\mathrm{R}$ & $\mathrm{R}$ & COX,OXA,AUG \\
\hline 16 & $\mathrm{R}$ & $\mathrm{S}$ & $\mathrm{S}$ & $\mathrm{R}$ & $\mathrm{S}$ & $\mathrm{S}$ & $\mathrm{R}$ & $\mathrm{R}$ & CAZ,COX,OXA,AUG \\
\hline 17 & I & $\mathrm{S}$ & $\mathrm{S}$ & $\mathrm{R}$ & $\mathrm{S}$ & $\mathrm{S}$ & $\mathrm{R}$ & $\mathrm{R}$ & COX,OXA,AUG \\
\hline $\begin{array}{l}\% \text { Resistance to } \\
\text { antibiotics }\end{array}$ & 71 & 0 & 6 & 94 & 0 & 5 & 77 & 100 & \\
\hline
\end{tabular}

Keys:

CAZ - Ceftazidine CTX - Cefotaxime, GEN - Gentamycin, COX - Cloxacillin, OFL - Ofloxacin, CRX - Cefuroxime, OXA - Oxacillin, AUG - Augmentin

$\mathrm{R}$ - Resistant, S - Sensitive, I - Intermediate 
Table.5 Phenotypic pattern of multiple antibiotic resistance (MAR) bacterial Isolates

\begin{tabular}{|c|c|c|c|c|}
\hline \multirow[b]{2}{*}{$\begin{array}{l}\text { Number of } \\
\text { antibiotics }\end{array}$} & \multirow[b]{2}{*}{ Combination of Antibiotics } & \multicolumn{2}{|c|}{ Number of Occurrence } & \multirow[b]{2}{*}{$\begin{array}{c}\text { Total Occurrence } \\
\mathbf{n}=106(\%)\end{array}$} \\
\hline & & $\begin{array}{c}\text { Gram negative } \\
n=49(\%)\end{array}$ & $\begin{array}{c}\text { Gram positive } \\
\mathbf{n}=57(\%)\end{array}$ & \\
\hline \multirow[t]{10}{*}{ 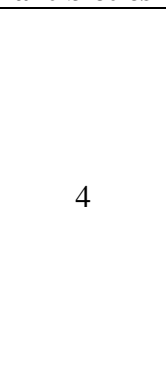 } & CAZ,COX,CRX AUG & - & $6(10.5 \%)$ & $6(5.7 \%)$ \\
\hline & CAZ COX OXA AUG & - & $9(16.8 \%)$ & $9(8.7 \%)$ \\
\hline & COX CRX OXA AUG & - & $4(7.0 \%)$ & $4(3.8 \%)$ \\
\hline & GEN CRX OXA AUG & - & $1(1.8 \%)$ & $1(0.9 \%)$ \\
\hline & COX OFL OXA AUG & - & $1(1.8 \%)$ & $1(0.9 \%)$ \\
\hline & CAZ,CRX OXA AUG & - & $1(1.8 \%)$ & $1(0.9 \%)$ \\
\hline & CRX GEN CXM AUG & $18(3 \overline{6} .7 \%)$ & - & $18(16.9 \%)$ \\
\hline & CAZ CRX GEN OFL & $2(4.1 \%)$ & - & $3(2.8 \%)$ \\
\hline & CAZ CRX GEN CXM & $2(4.1 \%)$ & - & $2(1.9 \%)$ \\
\hline & CRX CXM AUG NIT & $3(6.1 \%)$ & - & $2(1.9 \%)$ \\
\hline \multirow{7}{*}{5} & CAZ CRX GEN CXM AUG & $1(2.04 \%)$ & - & $1(0.9 \%)$ \\
\hline & CRX GEN CXM OFL AUG & $2(4.1 \%)$ & - & $2(4.1 \%)$ \\
\hline & CAZ COX CRX OXA AUG & - & $16(2 \overline{8} .1 \%)$ & $16(15.1 \%)$ \\
\hline & CRX CXM AUG NIT CPR & $1(2 . \overline{0} 4 \%)$ & _- & $1(0.9 \%)$ \\
\hline & CRX GEN CXM OFL AUG & $2(4.1 \%)$ & - & $2(4.1 \%)$ \\
\hline & CAZ CRX CXM AUG NIT & $1(2.04 \%)$ & - & $1(0.9 \%)$ \\
\hline & CAZ CRX GEN CXM AUG & $1(2.04 \%)$ & - & $1(0.9 \%)$ \\
\hline 6 & CRX CXM AUG NIT CPR & $1(2.04 \%)$ & - & $1(0.9 \%)$ \\
\hline
\end{tabular}

Keys:

CAZ - Cefotaxime, CTX - Ceftazidine, GEN - Gentamycin, COX - Cloxacillin,

OFL - Ofloxacin, CRX - Cefuroxime, OXA - Oxacillin, AUG - Augmentin,

NIT - Nitrofurantoin, CPR - Ciprofloxacin

Table.6 Plasmid Profile of Multiple Antibiotics Resistance (MAR) Bacterial Isolates

\begin{tabular}{lcccc}
\hline & Number of & MolecularWeight & \multicolumn{2}{c}{ Phenotype of resistance pattern } \\
\cline { 4 - 5 } Isolates & plasmids & oflasmid (kbp) & Number & Combinations \\
\hline Enterobacteraerogenes 75 & - & - & 4 & CAZ,CRX,GEN,CXM \\
Escherichia coli 101 & 1 & 23.130 & 4 & CAZ,CRX,CXM,AUG \\
Escherichia coli 14 & - & - & 4 & CRX,GEN,CXM,AUG \\
Pseudomonas aeruginosa 89 & 1 & 9.416 & 5 & CRX,CXM,AUG,NIT,CPR \\
Pseudomonas aeruginosa 17 & 1 & 9.416 & 5 & CRX,GEN,CXM,OFL,AUG \\
Escherichia coli 18 & 1 & 9.416 & 6 & CAZ,CRX,CXM,OFL,AUG,NIT \\
Pseudomonasaeruginosa 1 & - & - & 4 & CAZ,CRX,CXM,AUG \\
Enterobacteraerogenes24 & - & - & 4 & CAZ,CRX,CXM,AUG \\
Enterobacteraerogenes 28 & - & - & 4 & CAZ,CRX,CXM,AUG \\
Bacillus cerus 91 & - & - & 4 & CAZ,COX,CRX,AUG \\
Staphylococcus aureus 6 & - & - & 4 & CAZ,COX,OXA,AUG \\
Staphylococcus aureus 65 & - & - & 4 & COX,OFL,OXA,AUG \\
Enterococcus feacalis 45 & 1 & 23.130 & 5 & CAZ,COX,CRX,OXA,AUG \\
Enterococcus feacalis77 & 1 & 23.130 & 4 & COX,CRX,OXA.AUG \\
Bacillus cerus 27 & - & - & 5 & CAZ,COX,CRX,OXA,AUG \\
\hline
\end{tabular}

Keys:

CAZ - Cefotaxime, CTX - Ceftazidine, GEN - Gentamycin, COX - Cloxacillin, OFL - Ofloxacin,

CRX - Cefuroxime, OXA - Oxacillin,AUG - Augmentin , NIT - Nitrofurantoin, CPR - Ciprofloxacin 
Table.7 Antibiotic Susceptibility / Resistance Pattern of Gram Negative Isolates after curing

\begin{tabular}{|c|c|c|c|c|c|c|c|c|c|}
\hline \multirow[b]{2}{*}{ Test organism } & \multicolumn{8}{|c|}{ ANTIBIOTICS } & \multirow{2}{*}{$\begin{array}{l}\text { Phenotype of } \\
\text { Resistance pattern }\end{array}$} \\
\hline & CAZ & CRX & GEN & CXM & OFL & AUG & NIT & CPR & \\
\hline Escherichia coli 18 & $\mathrm{R}$ & $\mathrm{R}$ & $\mathrm{S}$ & $\mathrm{R}$ & $\mathrm{R}$ & $\mathrm{R}$ & $\mathrm{R}$ & $\mathrm{S}$ & CAZ,CRX,CXM,OFL,AUG,NI \\
\hline Pseudomonas aeruginosa & & $\mathrm{R}$ & $\mathrm{R}$ & $\mathrm{R}$ & $\mathrm{R}$ & $\mathrm{R}$ & $\mathrm{S}$ & $\mathrm{S}$ & CRX,GEN,CXM,OFL,AUG \\
\hline \% Resistance to antibiot & 50 & 100 & 50 & 100 & 100 & 100 & 50 & $\mathbf{0}$ & \\
\hline
\end{tabular}

Keys: CAZ - Cefotaxime, $\quad$ CRX - Cefuroxime, GEN - Gentamycin, $\quad$ CXM -Cefixime, OFL - Ofloxacin, AUG - Augmentin, NIT - Nitrofurantoin, $\quad$ CPR - Ciprofloxacin $\mathrm{R}$ - Resistant, $\mathrm{S}$ - Sensitive

Table.8 Antibiotic Susceptibility / Resistance Pattern of Gram Positive Isolate after curing

\begin{tabular}{|c|c|c|c|c|c|c|c|c|}
\hline \multirow[b]{2}{*}{ Test organism } & \multicolumn{7}{|c|}{ ANTIBIOTICS } & \multirow{2}{*}{$\begin{array}{l}\text { Phenotype of } \\
\text { Resistance pattern }\end{array}$} \\
\hline & CAZ & CTX & GEN & COX & OFL & CRX & OXA AUG & \\
\hline Enterococcus feacalis 45 & $\mathrm{R}$ & $\mathrm{S}$ & $\mathrm{S}$ & $\mathrm{R}$ & $\mathrm{S}$ & $\mathrm{R}$ & $\mathrm{R}$ & CAZ,COX,CRX,OXA,AUG \\
\hline
\end{tabular}

Keys:

$\begin{array}{ll}\text { CAZ - Cefotaxime, } & \text { CTX - Ceftazidine, } \\ \text { GEN - Gentamycin, } & \text { COX - Cloxacillin, } \\ \text { OFL - Ofloxacin } & \text { CRX - Cefuroxime, } \\ \text { OXA - Oxacillin, } & \text { AUG - Augmentin } \\ \text { R - Resistant, S - Sensitive }\end{array}$

Table.9 Plasmid Profile of Multiple Antibiotics Resistance (MAR)

Bacterial Isolates after Curing

Isolates

P/A Number

Molecular Weight of

plasmid

of plasmids (Kbp)

\begin{tabular}{llll} 
Escherichia coli 34 & A & & - \\
Enterobacter aerogenes 61 & A & & - \\
Bacillus cerus 1 & & A \\
\% Presence of Plasmid & & 0 \\
\hline Keys: P- Present & & A- Absent
\end{tabular}


Fig.1 Plasmid profile of Gram positive bacterial isolates

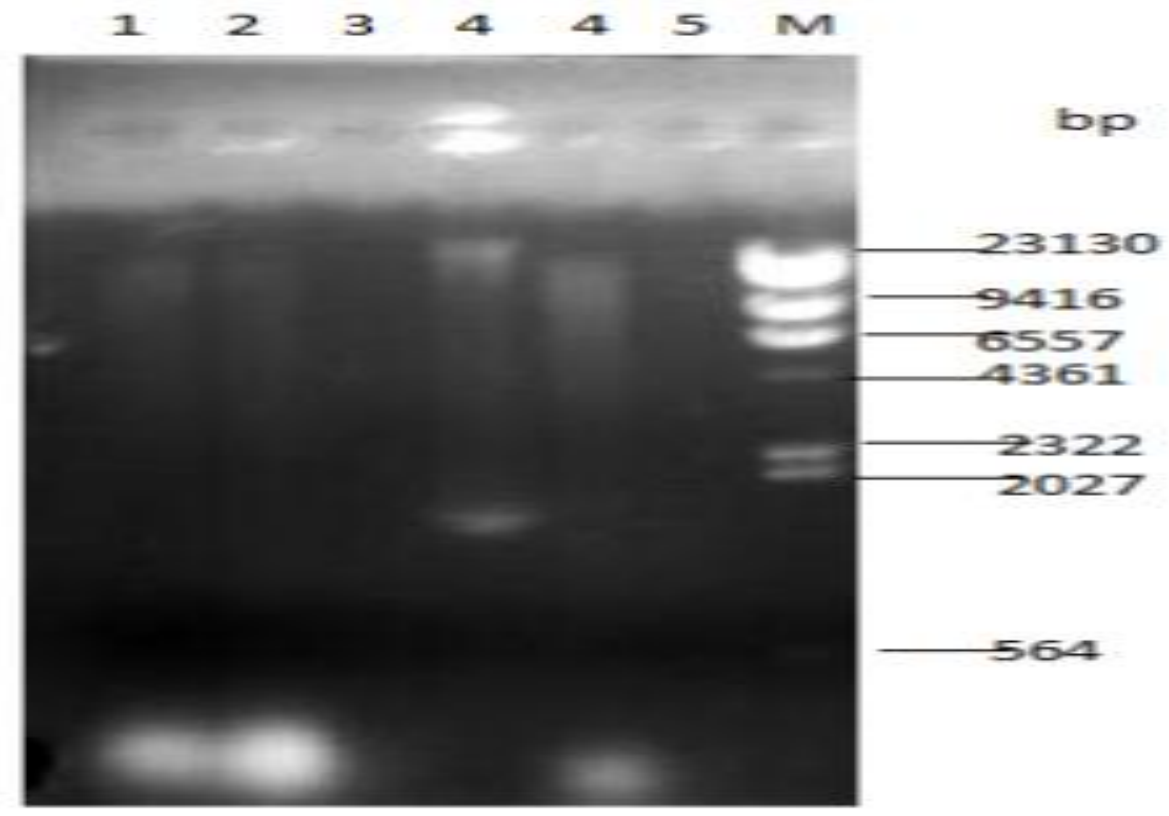

Fig.2 Plasmid profile of Gram negative bacterial isolates

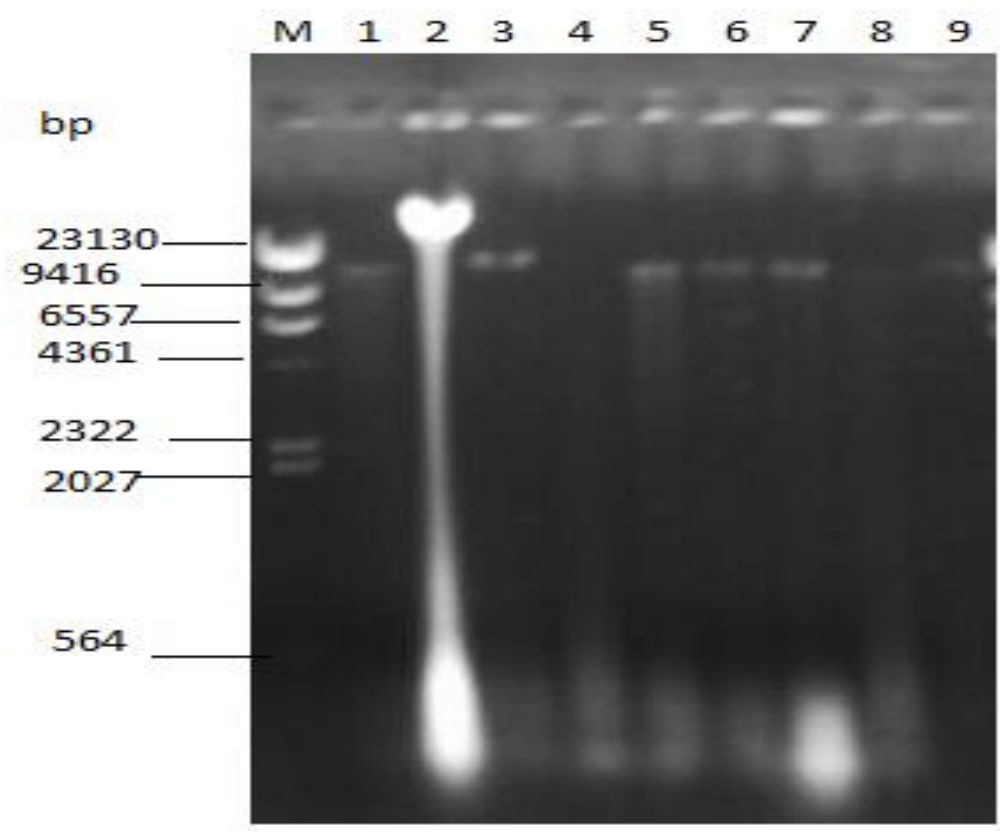

In this study, Escherichia coli and Pseudomonas aeruginosa which became susceptible to ofloxacin might be as a result of plasmid loss due to curing, suggesting that the initially observed resistance to these antibiotics might be plasmid mediated. Similar discoveries have been made by Vincent et al., (2010).
Interestingly after curing, E. coli was also observed to retain the sensitivity profile it exhibited before curing, which is in line with Thankam et al., (2014). In their study, the $E$. coli isolates showed resistance to cloxacillin, ampicillin, cephalexin, penicillin $\mathrm{V}$, erythromycin, vancomycin, cephalothin, oxacillin, nalidixic acid and clindamycin, all 
these did not change after plasmid curing. They also enumerated that analysis of cured and non-cured samples showed either no plasmid present or a very low copy number. However, the resistance of the isolates in this study to about $90 \%$ antibiotics even after plasmid curing indicates that the resistance to these drugs might not be plasmid mediated but might be attributed to environmental factors such as indiscriminate use of antibiotics, emergence of new strains of the organisms (Udeze et al., 2012); chromosomally mediated or results from other structural characteristics of the bacteria (Thankam et al., 2014; El-Saed et al., 2015).

\section{Conclusion and Recommendation}

This study has revealed that serious health hazards could result from the contamination of aquatic environment by leachate. From the research work, it is evident that the microbial load of the leachate is high and mainly comprised of coliform. Sewage and refuse should not be dumped into the stream water around the landfill site in order not to increase the nutrient availability of the water which will allow the growth of organisms in the water. There is also an urgent need for awareness to be created about the present situation of leachate and how it can affect the environment to alert the communities living around the area on the needs for treatment of the stream around the landfill before they can be used domestically.

Results in this study also demonstrated that the plasmid may be one of the important bacterial components responsible for resistance to antibiotics but chromosomal mutation or other structural characteristics of the bacteria might also be a major factor responsible for the resistance of these organisms to various antibiotics.
Further research and a detailed characterization is therefore needed to determine the major source of antibiotic resistance; while molecular identification should also be further investigated to ascertain the real identity of the probable microbes involved in antibiotic resistance in leachate samples from those Ebira communities. Meanwhile, a need for the development of new antibiotics to combat the infections caused by existing resistant strains should also be considered.

\section{References}

Akter, S., Rafiq, U. N., Rupa, F. A., Bari, L. $\mathrm{M}$ and Hossain, M. A. 2011. Antibiotic Resistance and Plasmid Profiles in Bacteria Isolated from Market Fresh Vegetables. Agric. Food Anal. Bacteriol., 1: 140-149.

APHA. 1985. Standard methods for examination of water and waste water. American Public

Cheesebrough, M. 2006. District Laboratory Practice in Tropical Countries (Part II). Cambridge University 2: 50-150.

Chen, H. and Zhang, M. 2013. Occurrence and removal of antibiotic resistance

CLSI. 2012. Performance standards for antimicrobial susceptibility testing; fifteenth informational supplement, Clinical and Laboratory Standard Institute Wayne, Pa. M100- S15, 25: 1.

El-Sayed, Z.M., Al-Ghamdi, A.K, Azhar, E.I., Ashishi, A.M. and Faidaha, H.S. 2015. Multidrug resistance bacterial strains and their associated plasmid profile. Life Sci. J., 12(1): 568-571.

Erb, A., Sturmer, T., Marre, R. and Brenner, H. 2007. Eur. J. Clin. Microbiol. Infect. Dis. 26: 83-90.

Fujita, M., Ike, M. and Suzuki, H. 1993. Screening of plasmids from waste 
water bacteria. Water Res., 27: 959953.

Garcia-Armisen, T., Vercammen, K., Passerat, J., Triest, D., Servais, P. and Cornelis, P. 2011. Antimicrobial resistance of heterotrophic bacteria in sewage-contaminated rivers. Water Res., 45: 788-796.

genes in municipal wastewater and rural domestic sewage treatment systems in eastern China. Environ. Int. 55: 9-14.

Health Association. $16^{\text {th }}$ Edition, Washington.

Ikem, A., Osibanjo. O., Sridhar, M.K.C. and Sobande, A. 2002. Evaluation of groundwater quality characteristic near two waste sites in Ibadan and Lagos, Nigeria. J. Water, Air and Soil Pollu., 140: 307-333.

Lewis, D.L. and Gattie, D.K. 2002. Pathogen risks from applying sewage sludge to land. Environ. Sci. Technol. J., 36: 286A-293A.

Liu, P.Y., Lau, Y.J. and Hu, B.S. 1995. Analysis of clonal relationships among isolates of Shigella sonnei by different molecular typing methods. J. Clin. Microbiol., 33: 1779-1783.

Luo, Y., Mao, D., Rysz, M., Zhou, Q., Zhang, H., Xu, L.J. and Alvarez, P. 2010.Trends in antibiotic resistance genes occurrence in the Haihe River, China. Environ. Sci. Technol., 44: 7220-7225.

Munir, M., Wong, K. and Xagoraraki, I. 2011. Release of antibiotic resistant bacteria and genes in the effluent and biosolids of five wastewater utilities in Michigan, Water Res., 45: 681-693.

Odeyemi, A.T., Awokunmi, E.E., Adebayo, A.A. and Fasoronti, O.F. 2015. Plasmid profile of Multi-drug resistance bacteria isolated from availablewater sources and Leachate samples from dumpsite at Ebira communities in Ekiti North Senatorial District, Ekiti State, Nigeria. Euro. J. Adv. Res. Biol. Life Sci., $\quad 3(1)$ : 2056-5984.

Odeyemi, A.T., Faweya, E.B., Agunbiade, O.R., and Ayeni, S.K. 2011. Bacteriological, Mineral and Radioactive Contents of Leachate Samples from Dump Sites of Ekiti State Government Destitiue Center in Ado Ekiti. Arch. Appl. Sci. Res., 3(4): 92-108.

Olutiola, P.O., Famurewa, O. and Sonntag, H.S. 2000. An introduction to General Microbiology (A practical Approach); Measurement of microbial growth. Pp. 101-111.

Palomino, J. and Martin, A. 2009. Drug susceptibility testing for Mycobacterium tuberculosis. Nitrate Reductase Assay, laboratory Manual. Institute of Tropical Medicine, Microbiology unit Antwerp, Belgium Pp $8 \quad-10$.

Paramasivam, S., Thangaradjou, T. and Kannan, L. 2007. Effect of natural preservatives on the growth of histamine producing bacteria. $J$. Environ. Biol., 28: 271-274.

Pruden, A., Pei, R., Storteboom, H. and Carlson, K.H. 2006. Antibiotic resistance genes as emerging contaminants: studies in northern Colorado. Environ. Sci. Technol., 40: 7445-7450.

Udeze, A.O., Adeyemi, A.T., Adeniji, F.O., Nwanze, J.C., Onoh, C., Okerentugba, P.O., Okonko, I.O. 2012. Plasmid Mediated Ampicillin Resistant

Bacterial Isolates from University of Ilorin Health Centre. New York Sci. J., 5(4): 56-63.

Vincent, N.C., Veronica, J.U., Stella, I., Etinosa, O.I. and Anthony, I., Okoh. 2010. Multidrug Resistance and Plasmid Patterns of Escherichia coli 
O157 and Other E. coli Isolated from Diarrhoeal Stools and Surface Waters from Some Selected Sources in Zaria, Nigeria. Int. J. Environ. Res. Public Health, 7: 3831-3841.

Wang, Y., Tang, W., Qiao, J. and Song, L., 2015. Occurrence and prevalence of antibiotic resistance in landfill leachate. Environ. Sci. Pollut. Res., DOI 10.1007/s11356-015-4514-7.

Wu, N., Qiao, M., Zhang, B., Cheng, W.D. and Zhu, Y.G. 2010. Abundance and diversity of tetracycline resistance genes in soils adjacent to representative swine feedlots in China. Environ. Sci. Technol., 44: 6933-6939.

Zhu, Y.G, Johnson, T.A., Su, J.Q, Qiao, M., Guo, G.X., Stedtfeld, R.D., Hashsham, S.A. and Tiedje, J.M. 2013. Diverse and abundant antibiotic resistance genes in Chinese swine farms. Proc. Natl. Acad. Sci., 110: $3435 \quad-3440$.

\section{How to cite this article:}

Odeyemi, A.T., O.S. Fasuan and O.Y. Olufowora. 2016. Plasmid Profile of Multiple Antibiotics Resistant (MAR) Bacteria Isolated from Leachate Samples in Ebira Communities of Ekiti Central and Ekiti South, Ekiti State, Nigeria. Int.J.Curr.Microbiol.App.Sci. 5(10): 478493. doi: http://dx.doi.org/10.20546/ijcmas.2016.510.054 